\title{
Retrofitting of Communal Open Spaces Towards Climate Comfort: Case Study Mega Block in New Belgrade
}

JSACE $1 / 10$

Retrofitting of Communal Open Spaces Towards Climate Comfort

Received 2014/09/21

Accepted after revision 2015/02/27

\section{Aleksandra Djukic}

Faculty of Architecture, University of Belgrade

Bulevar kralja Aleksandra 73/2, 11000 Belgrade, Serbia

*Corresponding author: adjukic@afrodita.rcub.bg.ac.rs

$\Gamma$

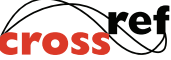

http://dx.doi.org/10.5755/j01.sace.10.1.8391
The focus of the research is mega-block in New Belgrade built in 1960 's, before and after transformation. The aim of research was to compare the parameters of bioclimatic urban design before and after the intervention. The results show decrease due to shading and evapotranspiration of $1^{\circ} \mathrm{C}$ to $2^{\circ} \mathrm{C}$, in the central part of communal open space and increase of temperature along the edges of the blocks, where new buildings were built, as well as the incasement of vaporization. Analyze of two options of urban design (before and after intervention) done with ENVI-met virtual simulation shows that the outdoor comfort of transformed communal open space deteriorated.

KEYWORDS: comfort, communal public space, mega block, quality, transformation.

The energy intensive way of life has created numerous problems that constantly threaten the endurance of ecosystems on global and local lever, while additionally the climate change begin to modify our perception of the living environment in terms of accepting its limitations and actions to mitigate the effects. The urban areas are the most affected by climate change, and the measurements have shown the increase of temperature in densely built urban zones - heat islands as well as substantial warming in temperature extremes (Jones et. al., 2009; IPCC, 2007). Urban heat islands have potential to compound and accelerate temperature rises in urban centers (Oke, 1995). During the last 55 years, in Serbia temperature has increased by over $1.4^{\circ} \mathrm{C} / 100$ years (Karadžić, Mijović, 2007). All prediction models for climate change point out an increase of temperature of about $3-4^{\circ} \mathrm{C}$ in Serbia until the end of 21 st century. This phenomenon will have the impacts on infrastructure, physical structure, vegetation, agriculture, water resources, health of citizens and mitigation to new created circumstances ( IPCC, 2007; UNECE, 2007).

High quality, safe, attractive, comfort and well-maintained communal public spaces are very important for sustainable cities and play a major part in economy, environment, social aspects and quality of life generally (Djukic, Vukmirovic, 2012). The concentration both of users and activities produces livability and vitality of districts and city (Hass-Klau, 1993; Hillier and Henson, 1984; Jacobs, 1972; Whyte, 1988, Gehl, 2004; Gehl at all., 2006). Recent research has shown that consideration of thermal comfort of outdoor spaces is important for improvement of the quality of space and increase of user's satisfaction as well as intensity of use. On the other hand, the

\section{Introduction}

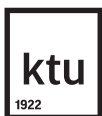

Journal of Sustainable Architecture and Civil Engineering Vol. 1 / No. 10 / 2015 pp. 5-12

DOI 10.5755/j01.sace.10.1.8391 (c) Kaunas University of Technology 
comfort of open public spaces depends on urban design and its morphological characteristics. The outdoor thermal environment is impacted by the surrounding surfaces and objects (Ichinose et al. 1999), materialization of ground surface (Lin et al. 2010), evaporation and evapotranspiration of plants (Robitu et al. 2006), shading by trees or constructed objects (Lin et al. 2010). Furthermore, contemporary approach to urban design includes another aspects of urban design quality such as: attractiveness, livability, legibility, robustness, readability, permeability and security. Although, urban design should satisfied all of this criteria, in this paper the focus was on comfort.

The focus of the research is mega-block in New Belgrade built in 1960 's, before and after transformation which has been done during the last two decades. The iconic modernist structures of New Belgrade have always been a symbol and a testimony of all ideological shifts in Yugoslav and Serbian society. More then 60 years of its urban existence has brought numerous adjustment and changes in its economic, social and functional structure, but its rigid and overscaled urban matrix has mostly remained untouched.

However, during the 1990s the process of a specific urban reconstruction started. The contemporary transformations of mega blocks in New Belgrade had an impact on the character of communal public spaces, its environment and qualities. The site occupancy index doubled in some cases as well as land occupancy. The materialization of the open space have also been changed, usually toward less greenery and more covered pavement.

The processes which shape our environment sometimes do not respond to actual needs of users, creating a gap between ambitious visions of professionals and politicians and our everyday life patterns. Block 21 was primarily conceived as a mono-functional residential block, but its reconstruction, conducted in two phases (during the 1990s and 2000s), instigated some typological changes. New functions were added (for ex. commercial and office spaces), as well as new residential structures, which were quite different from existing ones. Open community spaces were also transposed to another type, different in size, function, pattern of communication and accessibility.

The paper is developed around the hypothesis that recent changes of the block influenced the changes of the thermal comfort at open spaces and the case study of Block 21 should provide the results in the extent to which changes have occurred.

Comparative Analysis method was used for comparing the states of the Block 21 before and after the transformation. For the present state the field data collection was used. It includes observation of materialization of pavement, types of vegetation, use of space as well as microclimatic monitoring with portable meteorological station. Also, the photographs of study area before and after transformations are compared as well as urban projects for data about occupancy index and construction index of the block.

Two options of urban design have been tested with the selected microscale climate model ENVImet, one according the original plan for Block 21 (before the transformation, during the last two decades) and second one after the transformation (present situation). ENVI-met can estimate surface temperature, along with all the other microclimate parameters, for each finite element of the computational domain. All geo-referenced data can be extrapolated using the Xtract utility.

For this research, the ENVI-met 3.1 Beta 5 model was used. It is a tool specifically developed to study urban microclimate. ENVI-met is grid-based three-dimensional model for the simulation of airflow, heat and vapor exchange, turbulence and particle dispersion in urban areas. The software preform micro-scale simulations with a typical space resolution of 0.5 to 10 and 10 s time resolution. It takes into account the key modeling inputs, including site location, initial climatic parameters, soil and plant type, building structure, and thermal properties (Peng, 2013). It can generate three- 
dimensional distributions of radiation, temperature, heat flux, humidity and wind flow. Recently, the ENVI-met has been adapted mainly to simulate surface-plant-air interactions in urban canyons, and to predict climatic consequences of different urban design options (Bruce, 1998).

It generates output of temperature, humidity, wind speed, solar radiation, and other relevant data such as PMV (predicted mean vote). The model is based on the three-dimension CFD model, which can calculate meteorological parameters in each point of the grid (Bruce, 1998). Validation of the software has been done in different environments, especially for research concerning the urban morphologies (Gill et al., 2013).

In modeling analyses the the ENVI-met is using the shading factor to calculate the value of direct sun radiation. Sun position and intensity is set up by geographical location of researched site. On the other hand, as this is the conceptual model, ENVI-met has a assumption that all buildings set in the model are the high-density cases and share similar building mass. As such, the anthropogenic heat contribution is not separately accounted for. It can be treated as the background contribution in simulations, but as a lack of the informations about the site in this specific locations have not been used.

Two files are required by the software to run a complete simulation, a configuration file and an area file. The configuration file decides the settings for the simulation to run for example the date of simulation and duration, as well as basic meteorological information. The area input files are basically specifies the geometry of the model environment, such as:

_. Position and high of the buildings;

- Position and type of the plants;

_ Distribution of the surface materials and soil types;

_ Position of sources and receptors;

- Database links (database of soil, plants, material types);

_ Geographical positions of the location on earth.

The simulation was run for the $24^{\text {th }}$ July 2013 , which is representative of the day with typical summer values of temperature in Belgrade. Initial air temperature was $19.8^{\circ} \mathrm{C}$, wind speed $10 \mathrm{~m}$ above the ground was $3 \mathrm{~m} / \mathrm{s}$ from South East direction, relative humidity at $2 \mathrm{~m}$ was $50 \%$, specific humidity in $2500 \mathrm{~m}$ was $7 \mathrm{~g}$ water.kg air-1 and adjustment factor for solar input was 1. Model

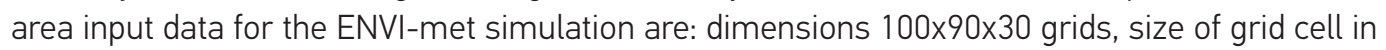
meters $d x=5 ; d y=5 ; d z=3$ and location of a block 21 is Belgrade $44.8167^{\circ} \mathrm{N}, 20.4667^{\circ} \mathrm{E}$. The simulation was run for 10.00 a.m., $12.00,02.00$ p.m., 04.00 p.m. and 06.00 p.m. The model was run for 24 hours from 6.00.am until 06.00 a.m. next day (minimum of 6 hours is required by ENVI-met).

In this research, two models have been created, which are Block 21 before and after 90's spatial layout, investigating impact of transformation of the Block 21 on the urban heat island effect. In both models, the simulations have been run at the same conditions. Air temperature and humidity at $0.8 \mathrm{~m}$ above ground have been extracted from the results.

The Block 21 is located in a moderate-continental climatic zone with four seasons. The average annual air temperature is $11.7^{\circ} \mathrm{C}$ and the hottest month is July $\left(22.1^{\circ} \mathrm{C}\right)$. The average annual number of days with temperature higher than $30^{\circ} \mathrm{C}$ (tropical days) is 31 and that of summer days with temperature higher than $25^{\circ} \mathrm{C}$ is 95 . The average annual rainfall on Belgrade and its surroundings is $669,5 \mathrm{~mm}$ and the rainiest months are May and June. The average annual insolation is 2.096 hours. The highest insolation of about 10 hours a day is in July and August, while December and January are the cloudiest, with insolation of 2 to 2.3 hours per day. The average number of

\section{Results}


snowy days is 27 , snow cover lasts from 30 to 44 days, and its average thickness is 14 to $25 \mathrm{~cm}$. Mean atmospheric pressure in Belgrade is 1,001 millibars and mean relative humidity is $69.5 \%$. Dominant and the most frequent wind is Kosava from South East.

Before the transformation

Fig. 1

Block 21 in New Belgrade before the transformation

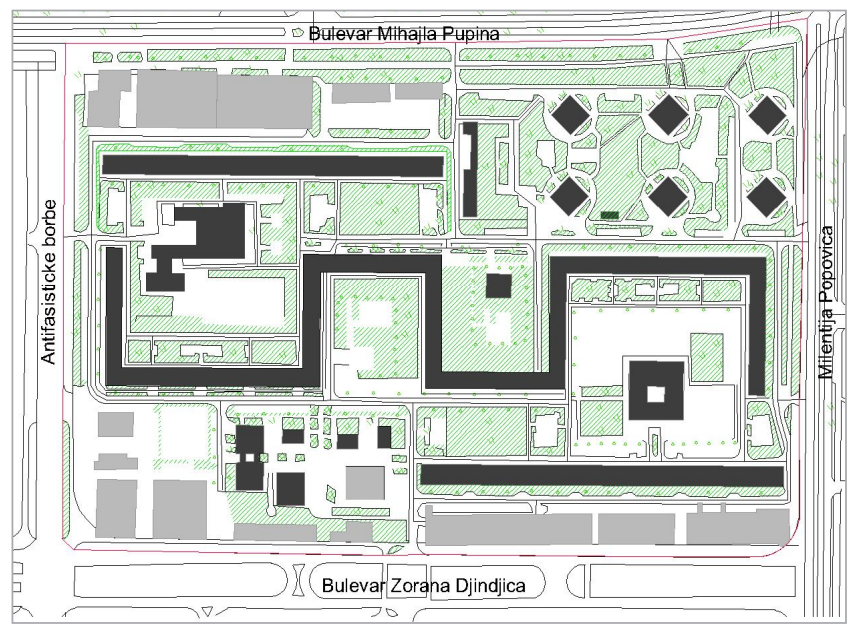

Fig. 2

Block 21 in New Belgrade after the transformation

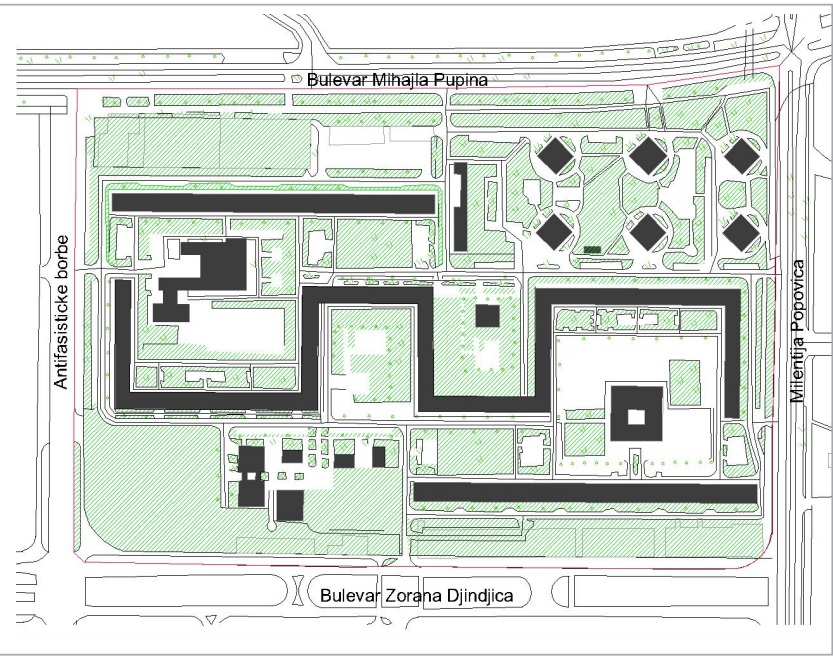

Fig. 3

Outputs from ENVI-met simulation for temperature - Block 21 in New Belgrade before the transformation (03.00. p.m.)

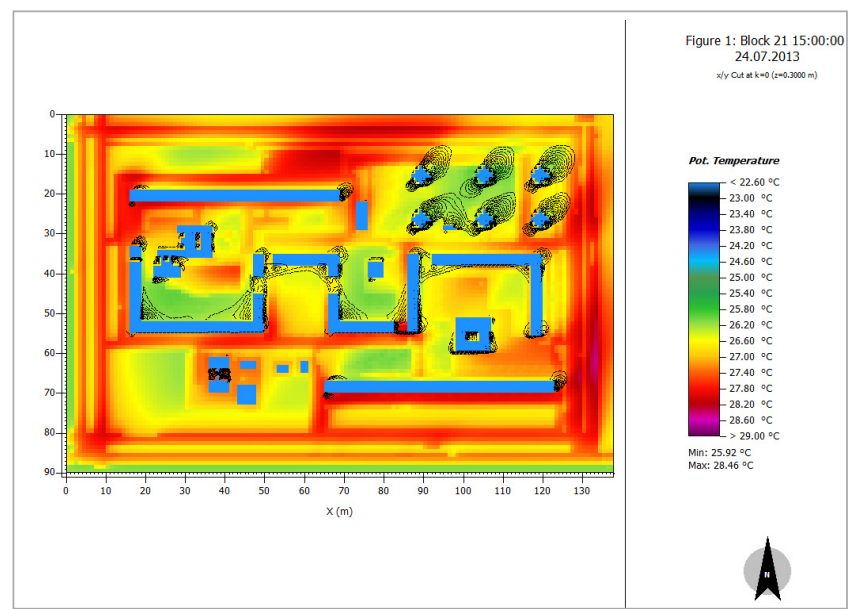
occupancy index of Block 21 was $54.68 \%$ (Fig. 1.), and now it is $70.24 \%$ (Fig. 2.). The green coverage were occupying $103,1722.54 \mathrm{~m}^{2}$ of the inner block space before 1990 and now it is covering $67,757.15 \mathrm{~m}^{2}$ within the block. On the other side, the vegetation which were planted 40 years ago, now had four times bigger treetops and create shaded areas within the inner side of the block.

Outputs from the ENVI-met simulation for air temperature, comparing the states before and after the intervention, shows decrease due to shading and evapotranspiration of $1{ }^{\circ} \mathrm{C}$ to $2^{\circ} \mathrm{C}$, in the central part of communal open space and around the new built structures (especially on the south west corner of the block) and increase of temperature along the edges of the blocks (where new buildings were built) (Fig. 3. and Fig. 4.).

The paving material remains the same, but there are slightly difference in covered area. Outputs from the ENVI-met simulations for mean radiant temperature shows significant reductions (between $5^{\circ} \mathrm{C}$ and $7^{\circ} \mathrm{C}$ ) in shaded areas, and some increase in temperature because of the maintaining and age of paving (Fig. 3. and Fig. 4.). The air temperatures over the parts with vegetation are much lower than those with concrete or asphalt, although some parts without vegetation still remain cool due to shading. The biggest difference could reach nearly $2.5^{\circ} \mathrm{C}$. Also, the air temperature in the 
parts covered by trees is about 0.5 $0.6^{\circ} \mathrm{C}$ lower than the parts covered by the grass. The air temperature is the result of interactions between various factors, therefore is highly dependent on the ambient conditions.

With the construction of the additional buildings next to Boulevard Zoran Djindjic (on the south) and Antifasisticke borbe Street (on the west) the temperature is rising inside the block. Especially we can see difference in the corner of the Boulevard Zoran Djindjic and

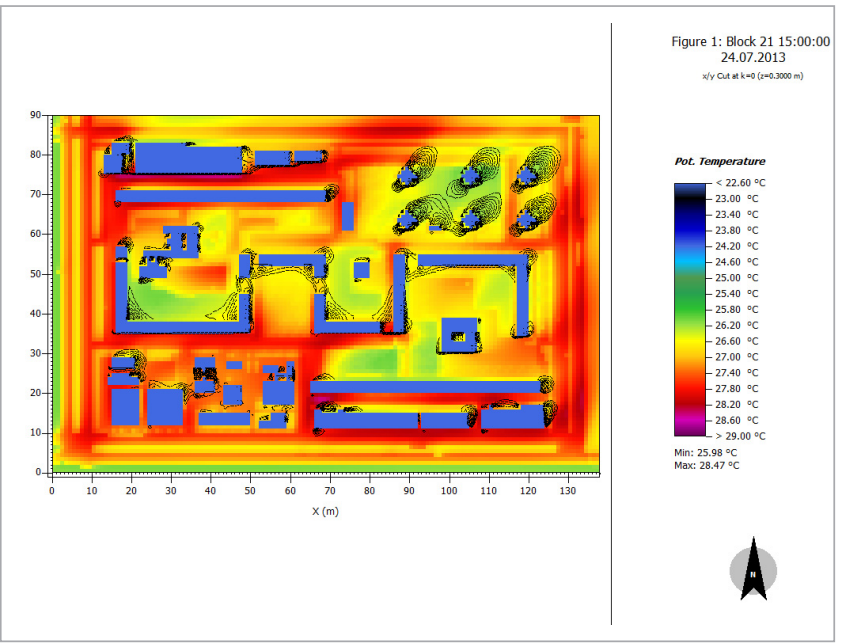
Milentija Popovica Street (on the east), where temperature is $0.5^{\circ} \mathrm{C}$ higher as well in the north part of the block (Boulevard Mihajla Pupina)

The percentage of the green surface within the Block 21 decreased two times after the transformation in 90 's. It is also observed that the trees are well positioned in the open spaces and during the period of 60 years treetops have provided shade for most of the space next to the buildings and for flats up to the second floor (Fig. 5).

In addition, the buildings which were built during the last decade create a few smaller inner yards within the block also provided more shades of open space (Fig. 1. and Fig. 2). This transformation influence the slightly decrease of temperature in new formed small open spaces, but new covered ground on the south and north of the block provide increase-ment of the temperature along the edges of it (Fig. 6.). On the other hand, lack of the maintenance of the pavement and bad choice of materials for pavement (albedo,emissivity, impermeability) also influence the slightly increase of the temperature.

Analyze of two options of urban design (before and after intervention) done with virtual simulation shows that communal open space has the potentials for improving microclimate in the Block 21. Retrofitting of the paving (albedo, emissivity, impermeability), more vegetation in the central area,

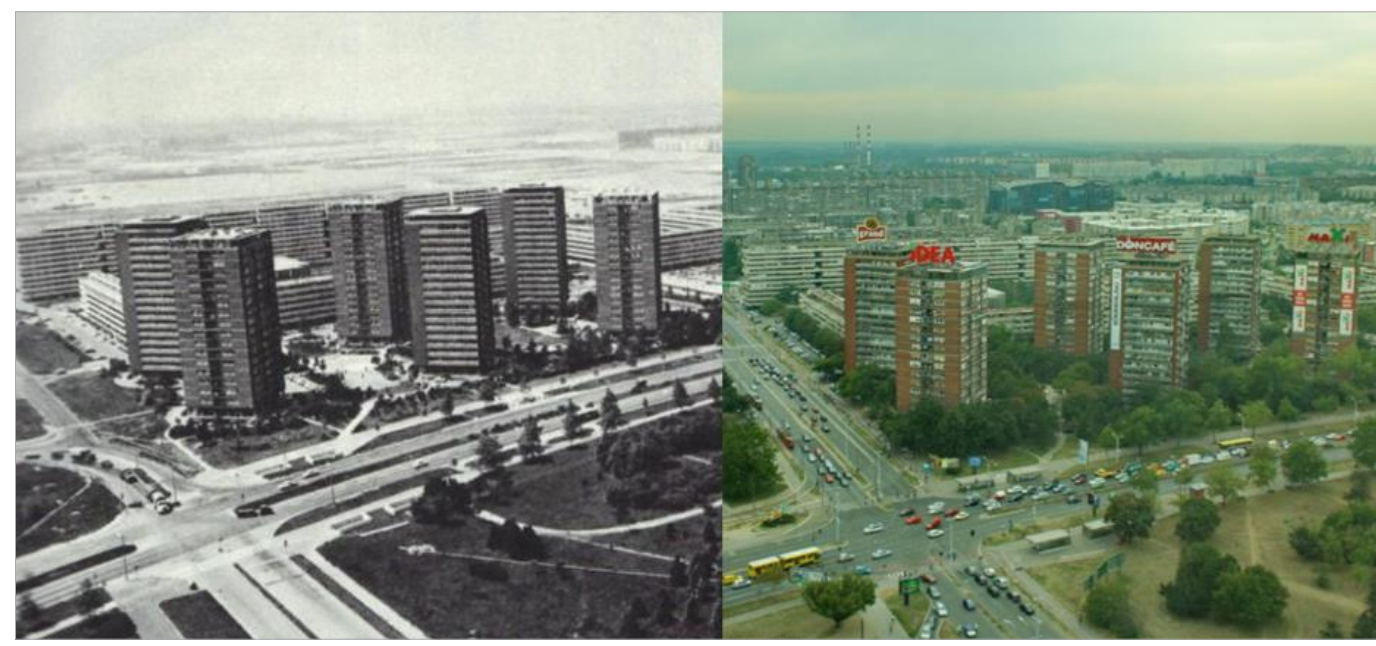

Fig. 4

Outputs from ENVI-met simulation for temperature - Block 21 in New Belgrade after the transformation

(03.00. p.m.)

\section{Discussion}

Fig. 5

Block 21 in New Belgrade in 1965 before the transformation (left) and in 2009 (right) 
Fig. 6

Outputs from ENVI-met simulation - difference in temperature in models before and after the transformation

Fig. 7

PMV for Block 21 14:00h, 24.07.2014 (before and after 90's)
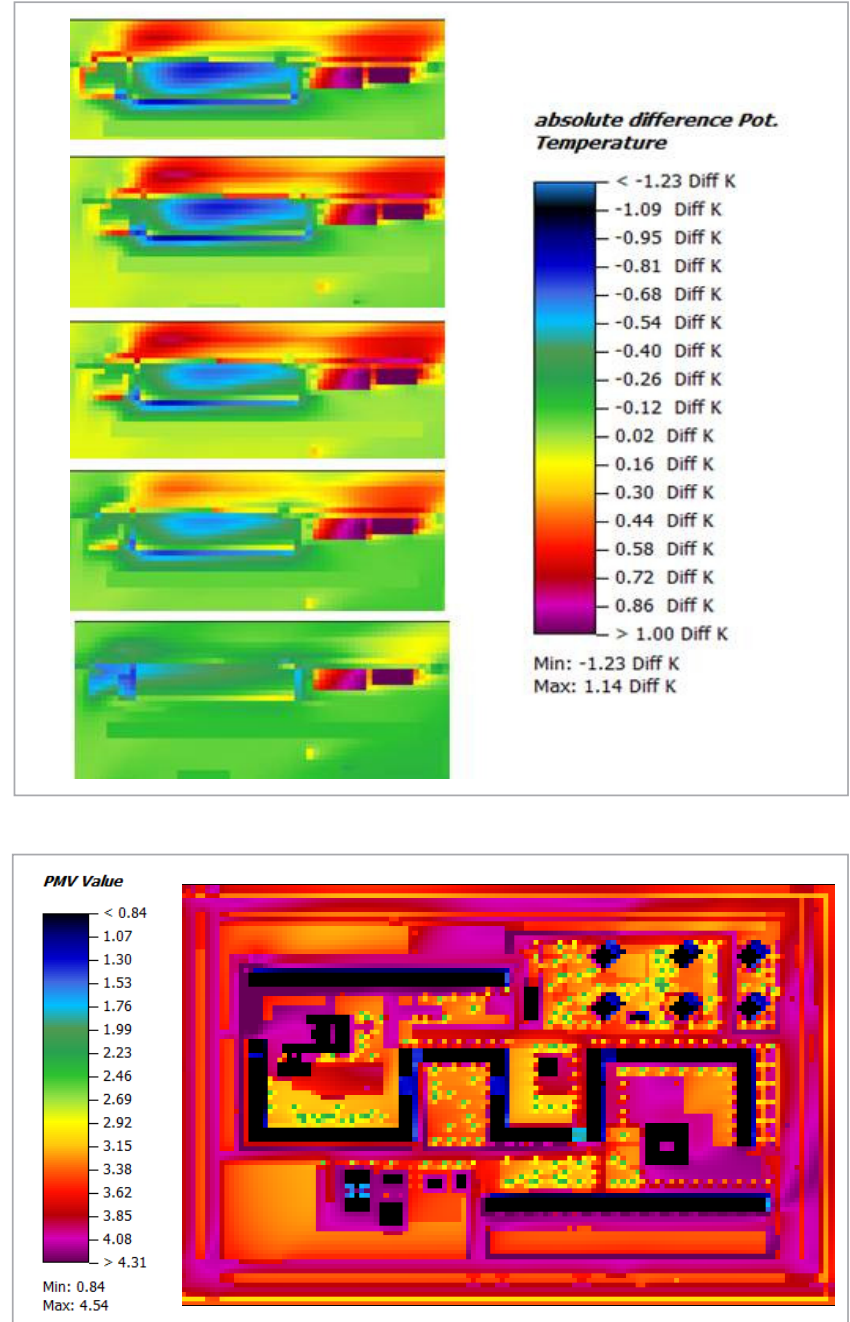
best known Biomet model. Based on Fanger 's (1974) model, it relates the energy balance of the human body to the personal comfort feeling of user exposed to the corresponding climates.

The PMV index predicts the mean response of a larger group of people according to the ASHRAE thermal sensation scale where +3 hot; +2 warm; +1 slightly warm, 0 neutral, -1 slightly cool, -2 cool, -3 cold.

The PMV index is expressed by P.O. Fanger as:

$P M V=(0.303 e-0.036 M+0.028) L$

PMV = Predicted Mean Vote Index; $M=$ metabolic rate; $\mathrm{L}=$ thermal load defined is the difference between the internal heat production and the heat loss to the actual environment - for a person at comfort skin temperature and evaporative heat loss by sweating at the actual activity level.

Analyzing thermal comfort in our research area following results have been produced: In figure 7 it is obvious that level of comfort is going beyond +3 (hot) and the average is between +2.9 and +4 . The construction of the new building has resulted with increase of area with the value PMV>+3.5. 
This study has presented impact new buildings have on the urban environment - the thermal comfort. The following conclusions have been drawn from the parametric studies based on ENVI-met:

The studies have shown that change of neighborhood geometry has a negative impact on urban environment - increase of the urban air temperatures at grade. The maximum air temperature increase in the Block 21 after 90's model, due to existence of new structures, is $2.4^{\circ} \mathrm{C}$ at around $2: 00 \mathrm{pm}$. Difference is bigger at the pick temperature, then in the rest of the day.

- As the wind is one of the most important factors for temperature flux, change of block's geometry against dominant wind has resulted to reduce of human comfort in outdoor space (PMV).

The new development has clearly damaged the amenity and comfort of the block. As the air temperature is reciprocal to air quality, so it is to assume that with the rise of the air temperature, the air quality is dropping down. But this is topic for another paper.

Communal open spaces in mega blocks should reinstate their significance as gathering points and points for recreation and leisure, representing a reflection of urban culture. During the retrofitting of the blocks the "cool" materials and vegetation should be considered as the tools for improving the microclimate of outdoor public space due to adopting to the substantial warming in temperature extremes brought by climate change. Bioclimatic urban retrofitting of existing open public space should be conceived as necessary action for fulfilling the role of open public space as the main place for social interactions during the hot summer conditions.

The undertaken research has confirmed that the microclimate of outdoor public space can than be largely influenced by: size and shape of open space, amount of vegetation, paving materials as well as its age and maintenance. It was shown that a smaller spaces, with a significant amount of vegetation can lead to more well balanced microclimate during the summer. Even the slightly changes in occupancy index of built area as well as the size and type of vegetation influence the microclimate.

Adaptation of the built environment to the substantial warming in temperature extremes in our cities, brought by climate change can be conceived as a set of retrofitting actions based on the principles of bioclimatic urban design. Furthermore, the microclimate offered by an urban open space has a strong impact on the thermal comfort of visiting pedestrians and consequently on the perception and the usage of the open space. However, in order to improve the communal open space in "mega blocks" in New Belgrade, it is necessary to fulfill the user's demands to apply bioclimatic urban design principles. To achieve the improvements it is necessary to integrate them into the types of interventions and guidelines into the urban plans and projects.

The paper is realized as part of the project "Spatial, Environmental, Energy and Social Aspects of Developing Settlements and Climate Change - Mutual Impacts" (TR36035), within the program Technological Development, both financed by the Ministry of Education and Science of the Republic of Serbia (2011-2015). The author is grateful to Srdjan Stankovic PhD student, who helped in ENVImet simulations.

\section{Acknow- ledgment}

Bruce M., Fleer, H. 1998. Simulating surfaceplant-air interactions inside urban environments with a three-dimensional numerical model, Environ. Model. Software, 13, 373-384. http://dx.doi.org/10.1016/S1364-8152(98)00042-5
ENVI-met Homepage. Available online: http:// www.envi-met.com (accessed10 September 2014).

Djukic, A., Vukmirovic, M. 2012. Walking as a climate friendly transportation mode in urban environment: case study Belgrade, IJTTE - Internatio-

References 
nal Journal for Trafic and Transport Engineering, Vol. 7, No. 4, 11/12, 214-230.

Fanger, P. O., Ostergaard, J., Olesen, S., \& Madsen, T. L. 1974. The effect on man's comfort of a uniform air flow from different directions. ASHRAE Transactions, 80(2), 142-157.

Gehl, J. 2004. Towards a fine city for people: Public spaces for public life, London, Copenhagen, Gehl Architects.

Gehl, J., Johansen, L., Reigstad, S. 2006. Close encounters between buildings, Urban Design International 11, 29-47. http://dx.doi.org/10.1057/ palgrave.udi.9000162

Gill, L., Hathway, E.A., Lange, E., Morgan, E., Romano, D. 2013. Coupling real-time 3D landscape models with microclimate simulations, International Journal of E-Planning Research (IJEPR), Vol. 2, 1, 1-19. http://dx.doi.org/10.4018/ ijepr.2013010101

Hass-Klau, 1993. The pedestrian and city traffic, London, Belhaven Press.

Hillier, B., Hanson, J. 1984. The social logic of space, London, Cambridge University Press. http://dx.doi.org/10.1017/CB09780511597237

Ichinose ,T., Shimodozono, K. \& Hanaki, K. 1999. Impact of anthropogenic heat on urban climate in Tokyo, Atmospheric Environment, No. 33, 3897-3909. http://dx.doi.org/10.1016/S13522310(99)00132-6

IPCC /Intergovernmental Panel on Climate Change/, 2007. Synthesis Report, Geneva, IPCC

Jacobs, J. 1961. The death and life of great American cities, New York, Peregrin.

Jones, P., Phino, P., Patterson, J., Tweed, C. (eds.), 2009. European carbon atlas: Low carbon urban built environment, Cardiff, The Welsh School of Architecture Cardiff University.

Karadžić, B., Mijović, A. (eds.), 2007. Environment in Serbia: an indicator - based review, Belgrade: Serbian Environmental Protection Agency, 45-55.

Lin B., L. Chambers L., Stackhouse Jr. P., WielickiB., Hu1, Y., Minnis, P., Loeb N., Sun, W., Potter, G., Min Q., Schuster G., Fan T.F. 2010. Estimations of climate sensitivity based on top-of-atmosphere radiation imbalance, Atmospheric Chemistry Physic., No. 10, 1923-1930.

Nikolopouloua, M., Steemers K. 2003. Thermal comfort and psychological adaptation as a guide for designing urban spaces, Energy and Building No.35, 95-101. http://dx.doi.org/10.1016/S03787788(02)00084-1

Oke, T.R. 1995. The heat island of the urban boundary layer: characteristics, causes and effects, World Climate in Cities, NATO ASI Series, Vol. 277, 81-107.

Peng, L.H., Jim, C.Y. 2013. Green-Roof Effects on Neighborhood Microclimate and Human Thermal Sensation, Energies 2013, 6, 598-618. http://dx.doi.org/10.3390/en6020598

Robity, M., Musy, M., Inard, C. \& Groleau, D. 2006. Modeling the influence of vegetation and water pond on urban environment, Solar Energy, No.80, 435-447. http://dx.doi.org/10.1016/j.solener.2005.06.015

UNECE (2007a) Belgrade Initiative: Enhancing the Regional SEE Cooperation in the Field of Climate Change, http://www.unece.org/fileadmin/ DAM/env/documents/2007/ece/ece.belgrade. conf.2007.20.e.pdf, (accessed 11 August 2014).

Whyte, W.H. 1988. City: Rediscovering the center. New York, Doubleday.

\section{About the author}

\section{ALEKSANDRA DJUKIC}

Associate Professor

Faculty of Architecture, University of Belgrade, Department of Urban design and Urban Planning

Main research area

Urban design, urban renewal and reconstruction

\section{Address}

Bulevar kralja Aleksandra 73/2, 11000 Belgrade, Serbia

Tel. +38163339861

E-mail: adjukic@afrodita.rcub.bg.ac.rs 